\title{
Pharmacologic targeting of the PI3K/mTOR pathway controls release of angioregulators from primary human acute myeloid leukemia cells and their neighboring stromal cells
}

\author{
Håkon Reikvam ${ }^{1,2}$, Ina Nepstad ${ }^{1}$, Øystein Bruserud ${ }^{1,2}$, Kimberley Joanne Hatfield $^{1,2}$ \\ 1 Section for Hematology, Department of Clinical Science, University of Bergen, Norway \\ 2 Department of Medicine, Haukeland University Hospital, Bergen, Norway. \\ Correspondence to: Øystein Bruserud, email: Oystein.Bruserud@helse-bergen.no \\ Keywords: Acute myeloid leukemia, cytokines, mTOR, PI3K, Angiogenesis, Bone marrow microenvironment, Pharmacological in- \\ tervention \\ Received: April 10, 2013, Accepted: May 10, 2013, \\ Published: May 11, 2013
}

This is an open-access article distributed under the terms of the Creative Commons Attribution License, which permits unrestricted use, distribution, and reproduction in any medium, provided the original author and source are credited.

\section{ABSTRACT:}

Acute myeloid leukemia (AML) is a heterogeneous and aggressive malignancy with poor overall survival. Constitutive as well as cytokine-initiated activation of PI3K/Akt/mTOR signaling is a common feature of AML patients, and inhibition of this pathway is considered as a possible therapeutic strategy in AML. Human AML cells and different stromal cell populations were cultured under highly standardized in vitro conditions. We investigated the effects of mTOR inhibitors (rapamycin and temsirolimus) and PI3K inhibitors (GDC-0941 and 3-methyladenin (3-MA)) on cell proliferation and the constitutive release of angioregulatory mediators by AML and stromal cells.

Primary human AML cells were heterogeneous, though most patients showed high CXCL8 levels and detectable release of CXCL10, Ang-1, HGF and MMP-9. Hierarchical clustering analysis showed that disruption of PI3K/Akt/mTOR pathways decreased AML cell release of CXCL8-11 for a large subset of patients, whereas the effects on other mediators were divergent. Various stromal cells (endothelial cells, fibroblasts, cells with osteoblastic phenotype) also showed constitutive release of angioregulatory mediators, and inhibitors of both the PI3K and mTOR pathway had anti-proliferative effects on stromal cells and resulted in decreased release of these angioregulatory mediators. PI3K and mTOR inhibitors can decrease constitutive cytokine release both by $A M L$ and stromal cells, suggesting potential direct and indirect antileukemic effects.

\section{INTRODUCTION}

Acute myelogenous leukemia (AML) is a heterogeneous malignancy characterized by clonal proliferation and accumulation of immature myeloblasts in the bone marrow $[1,2]$. The overall disease-free survival is only $40-50 \%$ even for younger patients below $60-65$ years of age who receive the most intensive chemotherapy [2], whereas long-term disease-free survival is uncommon for elderly patients and patients unfit for intensive therapy due to comorbidity. New and less toxic therapeutic strategies are therefore strongly needed in AML [3], and one alternative therapeutic strategy is inhibition of intracellular signaling through the phosphatidylinositol 3-kinase
(PI3K)/Akt/mammalian target of rapamycin (mTOR) pathway [4-6]. This pathway is important for regulation of cellular growth and metabolism and aberrant PI3K/ $\mathrm{Akt} / \mathrm{mTOR}$ signaling is found in several malignancies [7]. Pharmacological targeting of this pathway is therefore considered as a promising therapeutic approach in several cancer types [8-10], including AML [11-14].

Both normal and leukemic hematopoiesis seem to be supported by neighboring stromal cells in the bone marrow microenvironment, including fibroblast-like cells, osteoblasts and endothelial cells [15-18]. This supportive function is mediated through formation of so-called endosteal and vascular niches that may provide a sanctuary for subpopulations of malign cells to evade or circumvent drug-induced death [19]. Endothelial cells may also 
contribute to leukemogenesis through AML-induced bone marrow angiogenesis with an increased microvasculatory network in the bone marrow $[19,20]$. Bone marrow angiogenesis is regulated by the local cytokine network and a shift in the balance between pro- and antiangiogenic mediators in favor of angiogenesis [21]. Thus, the contribution of angiogenesis to leukemogenesis involves continuous interactions between the leukemic cells and the surrounding microenvironment including the stroma, and angiogenesis may then be supported by the release of angioregulatory cytokines both from the leukemic cells and from the nonleukemic stromal cells [19].

Previous experimental studies have used osteosarcoma cell lines with an osteoblastic phenotype [22, 23], well-characterized fibroblast cell lines [24], and normal endothelial cells $[18,23]$ as standardized

experimental models for the study of AML/stromal cell interactions. In this study, we used the same methodological approach to investigate effects of various $\mathrm{PI} 3 \mathrm{~K} / \mathrm{Akt} / \mathrm{mTOR}$ inhibitors and report that the constitutive release of angioregulatory mediators by AML and stromal cells is altered.

\section{RESULTS}

\section{Primary AML cells differ in their constitutive release of angioregulatory mediators}

Angiogenesis is important in leukemogenesis and represents a possible therapeutic target in AML [25]. We
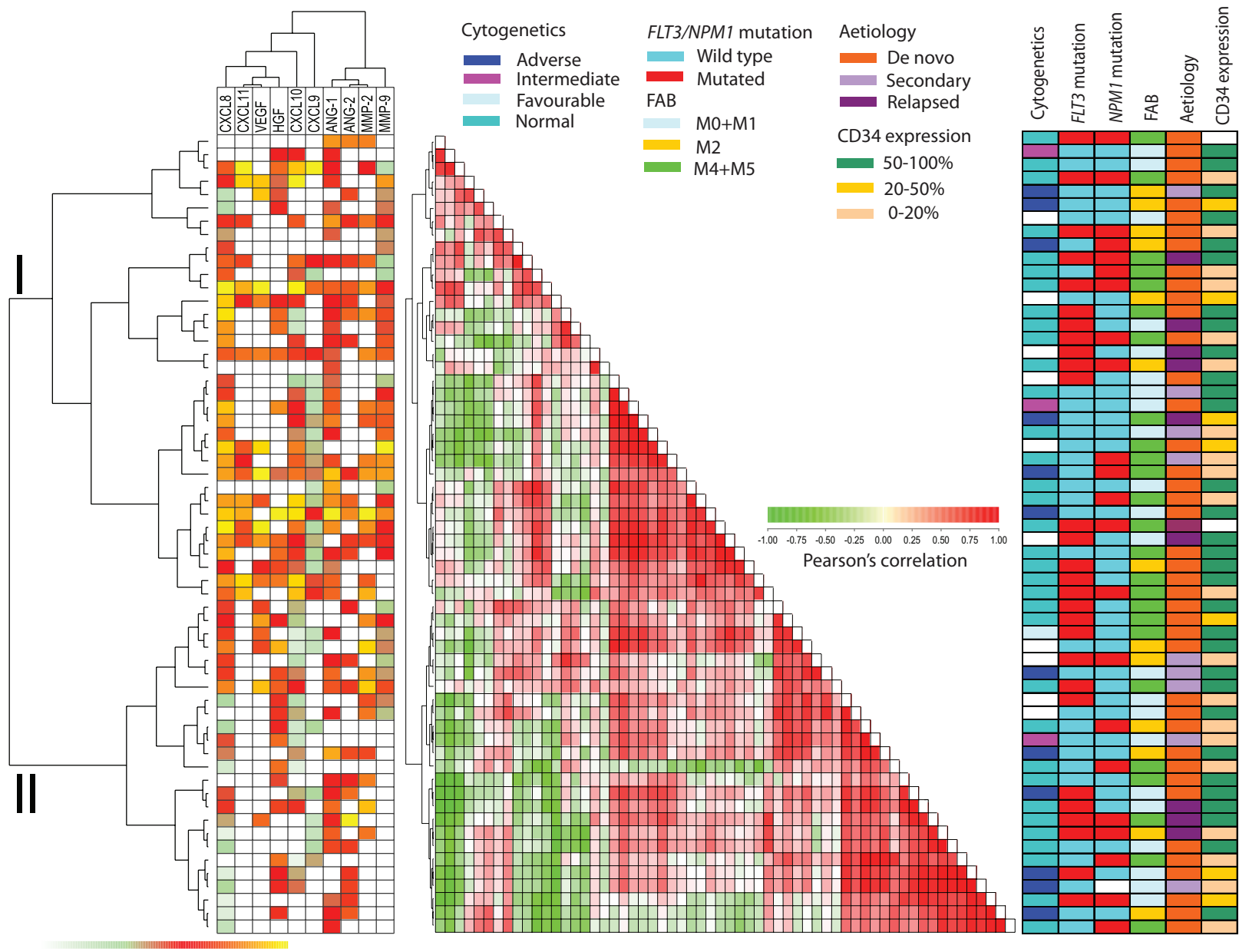

Low levels

High levels

Figure 1: Constitutive release of angioregulatory soluble mediators by primary human AML cells: unsupervised hierarchical cluster analysis (left), distance matrix analysis (middle) and comparison with clinical data (right). The leukemic cells were derived from 60 consecutive patients. For each mediator the concentrations were converted to percent of the maximum value obtained for the whole cohort and this value was then $\log (2)$ converted. The Pearson's correlation as distance measure and unweighted pair group method with arithmetic mean linkage was used to create a heatmap with additional unsupervised hierarchical clustering analysis. (LEFT) This panel shows the expression profile where low expression is marked with green and high expression with red to yellow. White represents undetectable values. The hierarchical clustering identified two main patient subsets referred to as cluster I and II (see Table 3). (MIDDLE) The correlation visualization with distance matrix displays the pairwise correlation between the 60 samples; deeper red or green colors indicate a higher positive/negative correlation between the 10 mediators in each sample. (RIGHT) The right panel shows characteristics for each individual patient (genetic abnormalities, morphological differentiation and etiology). 
Table 1: Main characteristics of the $60 \mathrm{AML}$ patients included in the study.

\begin{tabular}{|c|c|c|}
\hline \multicolumn{2}{|c|}{ Patient characteristics } & $\begin{array}{l}\text { Number } \\
\text { (percent) }\end{array}$ \\
\hline \multicolumn{3}{|c|}{ Demographic data and disease history } \\
\hline Gender (numbers) & Male/female & $33(55) / 27(45)$ \\
\hline \multirow[t]{3}{*}{ AML history } & \begin{tabular}{|l|} 
De novo \\
\end{tabular} & $41(68.3)$ \\
\hline & \begin{tabular}{|l|} 
Secondary \\
\end{tabular} & $9(15.0)$ \\
\hline & Relapsed & $10(16.7)$ \\
\hline \multicolumn{2}{|c|}{ AML cell differentiation } & \\
\hline \multirow[t]{3}{*}{ FAB classification } & M0-1 & $22(36.6)$ \\
\hline & M2 & $13(21.7)$ \\
\hline & M4-5 & $25(41.7)$ \\
\hline \multirow[t]{3}{*}{ CD34 expression } & $0-20 \%$ & $20(33.3)$ \\
\hline & $20-50 \%$ & $7(11.7$ \\
\hline & $50-100 \%$ & $31(51.7)$ \\
\hline \multicolumn{2}{|c|}{ Genetic abnormalities* } & \\
\hline \multirow[t]{4}{*}{ Cytogenetics } & Favorable & $1(1.7)$ \\
\hline & Intermediate & $3(5.0)$ \\
\hline & Adverse & $12(20)$ \\
\hline & Normal & $34(56.7)$ \\
\hline \multirow[t]{2}{*}{ FLT3† } & ITD & $25(41.7)$ \\
\hline & TKD & $4(6.7)$ \\
\hline NPM1 & Mutated & $22(36.7)$ \\
\hline
\end{tabular}

q)Presented as the percentage of positive cells in flow cytometric analysis.

*)Favorable cytogenetics includes one patient with inv(16), intermediate includes three patients with either $+8,+14$ or +13 , adverse includes eight patients with multiple $(\geq 3)$ abnormalities, two patients with -7 and two patients with -5 .

$\dagger)$ One patient had both a FLT3-ITD and a FLT3-TKD mutation.

quantified the constitutive release of 10 angioregulatory cytokines during in vitro culture of primary human AML cells derived from 60 unselected patients. The overall results are summarized in Table 2. The majority of patients showed detectable release of CXCL8, CXCL10, Ang-1, HGF and MMP-9, but the levels showed a wide variation between individual patients. CXCL8 levels (median level $12002 \mathrm{pg} / \mathrm{mL}$ ) were generally higher than the other cytokine levels, but HGF was usually also released at relatively high levels (median level $409 \mathrm{pg} / \mathrm{mL}$ ).

We performed an unsupervised clustering of the 60 patients with regard to their angioregulatory profile, i.e. their constitutive cytokine release (Fig. 1). The values were first normalized by dividing with the maximum release value, and the angioregulatory mediators then formed two major clusters including (i) the proangiogenic HGF, VEGF and CXCL8 together with the antiangiogenic chemokines CXCL9-11 and (ii) Ang-1/2 together with MMP-2/9. The patients could also be divided into two major clusters, the main differences between them being increased release of CXCL8, CXCL9 and Ang-1
Table 2: Constitutive release of angioregulatory factors by primary human AML cells derived from 60 consecutive patients. The levels are presented as median and range.

\begin{tabular}{|l|l|l|}
\hline $\begin{array}{l}\text { Angiogenic } \\
\text { factors }\end{array}$ & $\begin{array}{l}\text { Number of } \\
\text { patients with } \\
\text { detectable } \\
\text { release }\end{array}$ & $\begin{array}{l}\text { Cytokine levels (pg/ } \\
\text { ml) for patients with } \\
\text { detectable release }\end{array}$ \\
\hline CXCL8 & 54 & $12002(14.2-189$ 169) \\
\hline CXCL9 & 30 & $27.5(6.9-18368)$ \\
\hline CXCL10 & 46 & $191(2.78-25468)$ \\
\hline CXCL11 & 16 & $246.8(40.2-2645)$ \\
\hline Ang-1 & 45 & $121(18.6-4337)$ \\
\hline Ang-2 & 25 & $19.0(9.3-415)$ \\
\hline VEGF & 18 & $34.4(5.4-197)$ \\
\hline HGF & 31 & $409(40.0-7736)$ \\
\hline MMP-2 & 26 & $1530(230-10900)$ \\
\hline MMP-9 & 38 & $4290(250-379400)$ \\
\hline
\end{tabular}

Table 3: Biological characteristics of the two major patient subsets identified by cluster analysis of the constitutive release of soluble mediators (cytokines and MMPs, see right part of Fig. 1).

\begin{tabular}{|c|c|c|c|}
\hline Mediator & Cluster I & Cluster II & p-value \\
\hline CXCL8 & $\begin{array}{l}23718(3.5- \\
289169)\end{array}$ & $413(3.5-43561)$ & 0.0002 \\
\hline CXCL9 & $\begin{array}{ll}12.7 & (3.8-18 \\
368) & \\
\end{array}$ & $3.8(3.8-49.8)$ & 0.0066 \\
\hline CXCL10 & $\begin{array}{ll}540 \quad(1.7-25 \\
468) & \\
\end{array}$ & $10.0(1.7-574)$ & 0.0004 \\
\hline CXCL11 & $\begin{array}{l}13.9 \\
2645)\end{array}$ & $13.9(13.90-13.9)$ & 0.0060 \\
\hline Ang-1 & $\begin{array}{l}111 \\
4337)\end{array}$ & $73.3(3.5-1170)$ & n.s \\
\hline Ang-2 & $\begin{array}{l}8.3 \\
67.4)\end{array}$ & $8.3(8.3-415)$ & n.s \\
\hline VEGF & $5.0(5.0-197)$ & $5.0(5.0-75.4)$ & n.s \\
\hline HGF & $\begin{array}{l}40.0 \quad(40.0- \\
7736)\end{array}$ & $112(10.0-2440)$ & n.s \\
\hline MMP-2 & $\begin{array}{l}160 \quad(160-10 \\
900)\end{array}$ & $160(160-5660)$ & n.s \\
\hline MMP-9 & $\begin{array}{l}4090 \quad(160- \\
379400)\end{array}$ & $160(160-21860)$ & $<0.0001$ \\
\hline
\end{tabular}

The levels of the soluble mediators are presented as median concentrations $(\mathrm{pg} / \mathrm{ml})$, the variation range is given in parenthesis. The Mann-Whitney U test was used for the statistical comparison (ns; not significant). 
in the upper cluster I (Table 3). Thus, the difference in angioregulatory profiles between individual patients is mainly caused by differences in their chemokine release (Table 3), and quantitatively major differences between CXCL8 release was observed between the two clusters. The two clusters did not differ with regard to AML etiology (de novo versus secondary/relapse) differentiation (FAB classification or CD34 stem cell marker expression), cytogenetic abnormalities, and/or frequency of NPM1 or
FLT3 mutations (Table 3).

\section{Both PI3K and mTOR inhibitors can alter the constitutive release of angioregulatory mediators by primary human AML cells}

We investigated the effects of two mTOR inhibitors (rapamycin $1 \mu \mathrm{M}$, temsirolimus $0.1 \mu \mathrm{M}$ ) and two PI3K

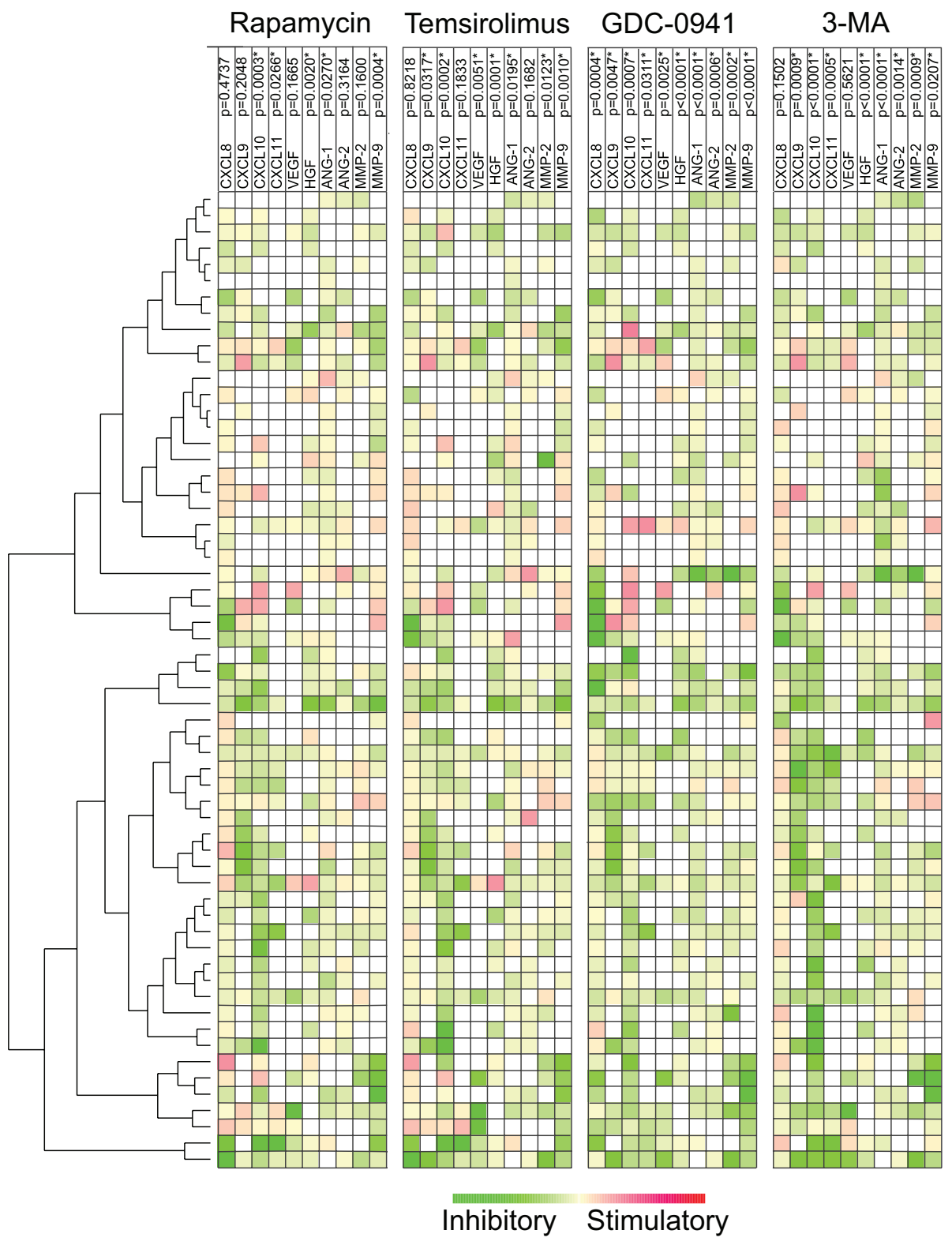

Figure 2: The effect of mTOR (rapamycin, temsirolimus) and PI3K inhibitors (GDC0941, 3-MA) on the constitutive release of angioregulatory mediators by primary human AML cells. Leukemic cells from 60 consecutive patients were examined. For each mediator the concentration in treated cultures were divided with the concentration in control cultures before values were $\log (2)$ converted. The effects of rapamycin $1 \mu \mathrm{M}$, temsirolimus $0.1 \mu \mathrm{M}$, GDC-0941 $1 \mu \mathrm{M}$ and 3-MA $1 \mathrm{mM}$ on the release of 10 different angioregulatory mediators were determined. The Euclidian correlation test with complete linkage was used to make a heatmap with additional unsupervised hierarchical clustering analyses. The patients could be divided into two main clusters based on the overall pharmacological effects on the release of the soluble mediators. The green color indicates decreased and red color increased mediator levels. The mediators are listed at the top together with the corresponding p-values when the overall pharmacological effects for the whole patient population were analyzed. * indicates a significant reduction in concentration. 
Table 4: Effects of mTOR and PI3K inhibitors on the constitutive release of angioregulatory mediators by primary human AML cells.

\begin{tabular}{|c|l|l|l|l|}
\hline Soluble Mediator & Rapamycin & Temsirolimus & GDC-0941 & 3-MA \\
\hline \multirow{2}{*}{ CXCL8 } & $96.5 \%$ & $103.0 \%$ & $66.0 \%$ & $93.5 \%$ \\
& 0.4737 & 0.8218 & 0.0004 & 0.1502 \\
\hline \multirow{2}{*}{ CXCL9 } & $76.0 \%$ & $69.0 \%$ & $50.0 \%$ & $32.5 \%$ \\
& 0.2048 & 0.0317 & 0.0047 & 0.0009 \\
\hline \multirow{2}{*}{ CXCL10 } & 50.5 & 52.0 & 53.0 & 29.0 \\
& 0.0003 & 0.0002 & 0.0007 & 0.0001 \\
\hline \multirow{2}{*}{ CXCL11 } & 70.5 & 81.0 & 56.5 & 35.0 \\
& 0.0226 & 0.183 & 0.0311 & 0.0005 \\
\hline \multirow{2}{*}{ Ang-1 } & 89.0 & 89.0 & 76.0 & 71.0 \\
& 0.0270 & 0.0195 & $<0.0001$ & $<0.0001$ \\
\hline \multirow{2}{*}{ Ang-2 } & 97.0 & 88.0 & 85.0 & 79.0 \\
& 0.3164 & 0.1682 & 0.0006 & 0.0014 \\
\hline \multirow{2}{*}{ VEGF } & 64.0 & 41.0 & 51.0 & 86.0 \\
& 0.1665 & 0.0051 & 0.0255 & 0.5621 \\
\hline \multirow{2}{*}{ HGF } & 75.0 & 72.0 & 57.5 & 57.0 \\
\hline \multirow{2}{*}{ MMP-2 } & 0.0020 & 0.0001 & $<0.0001$ & $<0.0001$ \\
\hline \multirow{2}{*}{ MMP-9 } & 96.0 & 70.5 & 54.3 & 58.5 \\
& 0.1640 & 0.0123 & 0.0002 & 0.0009 \\
\hline
\end{tabular}

The results are presented as the median \% inhibition (upper value) of mediators released after drug treatment compared to levels in control cultures without drugs. The corresponding p-value (lower value) is shown where statistically significant differences are marked in bold. The drugs were tested at the following concentrations: rapamycin $1.0 \mu \mathrm{M}$, temsirolimus $0.1 \mu \mathrm{M}$, GDC-0941 $1.0 \mu \mathrm{M}$ and 3-MA 1.0 $\mathrm{mM})$.

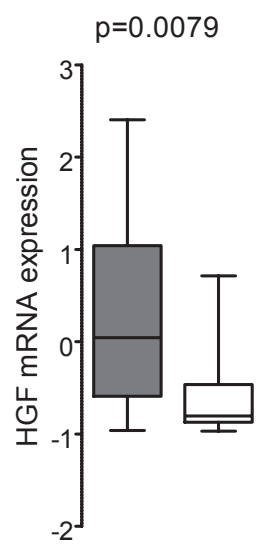

HGF

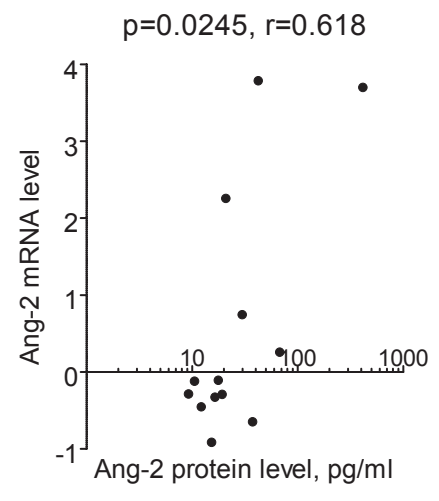

Figure 3: Associations between mRNA levels and supernatant protein levels for HGF and Ang-2. mRNA levels in primary AML cells were compared with proteins levels measured after AML cell culture for 24 hours. (LEFT) Both mRNA and supernatant protein levels were available for 31 patients, and mRNA HGF levels differed significantly when comparing the 19 patients with detectable constitutive HGF secretion (grey box) with the 12 patients showing no detectable HGF release (white box) (Mann-Whitney U-test, $\mathrm{p}=0.0079$ ). (RIGHT) mRNA Ang-2 levels showed a significant correlation with the Ang-2 protein concentration in culture supernatants of AML cells derived from 13 patients $(\mathrm{p}=0.0245, \mathrm{r}=0.618$, Pearson's correlation). inhibitors (GDC-0941 $1 \mu \mathrm{M}$, 3-MA $1 \mathrm{mM}$ ) on the release of 10 angioregulatory mediators. Levels of mediators released by AML cells are shown in Table 2 and the results from the statistical analyses are summarized in Table 4. The mTOR inhibitors rapamycin and temsirolimus showed similarities in their inhibitory profile with a strong reduction of CXCL10, HGF and MMP-9 levels corresponding to $\mathrm{p}$-values $\leq 0.002$, whereas there was no significant reduction of the high CXCL8 levels. In contrast, the pan-PI3K inhibitor GDC-0941 caused a statistically significant reduction of all mediators, although the reduction of CXCL9, CXCL11 and VEGF was relatively small. The PI3K-class III inhibitor 3-MA had an intermediate effect and caused a strong inhibition of CXCL9-11, HGF, Ang-1/2 and MMP-2. Thus, even though these pharmacological agents inhibit various steps in the same intracellular signaling pathway, they differ in their effects on the constitutive cytokine release and the PI3K inhibitors then cause a more extensive alteration of the angioregulatory profile than mTOR inhibitors.

We then performed a clustering analysis of the 60 patients based on the pharmacological effects on the constitutive release of the 10 mediators (Fig. 2). Two major patient clusters were found, and these two clusters differed especially with regard to the pharmacological inhibition of constitutive CXCL9-11 release, whereas the 
Table 5: Constitutive release of angioregulatory soluble mediators by different stromal cell lines

\begin{tabular}{|l|l|l|l|l|l|l|l|l|}
\hline CELL TYPE & $\begin{array}{l}\text { CXCL8/ } \\
\mathbf{I L - 8} \\
\mathbf{p g} / \mathbf{m l}\end{array}$ & $\begin{array}{l}\text { CXCL12 } \\
\mathbf{p g} / \mathbf{m l}\end{array}$ & $\begin{array}{l}\text { Ang-1 } \\
\mathbf{p g} / \mathbf{m l}\end{array}$ & $\begin{array}{l}\text { Ang-2 } \\
\mathbf{p g} / \mathbf{m l}\end{array}$ & $\begin{array}{l}\text { VEGF } \\
\mathbf{p g} / \mathbf{m l}\end{array}$ & $\begin{array}{l}\text { bFGF } \\
\mathbf{p g} / \mathbf{m l}\end{array}$ & $\begin{array}{l}\text { MMP-2 } \\
\mathbf{n g} / \mathbf{m l}\end{array}$ & $\begin{array}{l}\text { MMP-10 } \\
\mathbf{p g} / \mathbf{m l}\end{array}$ \\
\hline Endothelial cells (HUVEC) & 12.0 & 42.3 & 171.2 & 300.0 & 325.3 & 4.7 & 7.2 & 1504.4 \\
\hline Endothelial cells (HAAE-1) & 573.1 & 68.3 & 193.9 & 85.3 & 9.7 & 23.4 & 30.3 & 668.1 \\
\hline Endothelial cells (HIAE-101) & 540.2 & 48.4 & 127.1 & 76.2 & 129.1 & 71.4 & 16.2 & 221.4 \\
\hline $\begin{array}{l}\text { Bone marrow stromal cells } \\
\text { (2M-302) }\end{array}$ & 797.8 & 559.1 & 3423.1 & 598.4 & 730.3 & nd & 22.7 & 16.0 \\
\hline Fibroblast (HFL1) & 79.6 & 109.7 & 229.0 & 48.0 & 11.9 & nd & 6.9 & 16.0 \\
\hline Fibroblast (Hs27) & 320.9 & 49.6 & 72.8 & 160.3 & nd & nd & 11.4 & 285.1 \\
\hline Osteoblasts (CC-2538) & 676.5 & 775.5 & 2473.6 & 676.4 & 563.8 & nd & 25.7 & n.d \\
\hline Osteoblastic cells (Cal-72) & 12.1 & 37.4 & 672.9 & 19.9 & 671.1 & nd & 36.2 & 9.9 \\
\hline Osteoblastic cells (SJSA-1) & 1361.8 & 24.8 & 46.5 & 184.5 & 153.5 & nd & 18.2 & 64.2 \\
\hline $\begin{array}{l}\text { Adherent osteosarcoma } \\
\text { cell line (KHOS-312H) }\end{array}$ & 41.2 & 104.2 & nd & nd & 781.7 & 15.8 & 8.5 & nd \\
\hline
\end{tabular}

The table presents the levels in culture supernatants. nd; not detectable. None of the stromal cells released detectable levels of CXCL9-11, MMP-9 or HGF.

pharmacological effects on release of the other cytokines showed a wide variation and did not differ significantly between the two major clusters.

Finally, we also performed an unsupervised clustering for the 60 AML patients based on the pharmacological effects on release of angioregulatory mediators. The cytokine clustering showed similarities between the four inhibitors and confirmed the observations described above (see Fig. 1): (i) the chemokines clustered separately from the other mediators (ii) VEGF clustered together with HGF, the two angiopoietins clustered together, and the two MMPs clustered together (data not shown).

\section{Association between protein and mRNA levels for angioregulatory cytokines}

We used microarray analysis to examine mRNA levels in non-cultured leukemia cells for 31 of the 60 AML patients investigated for their constitutive cytokine release. We performed both (i) correlation analysis between detectable cytokine protein levels and mRNA levels and (ii) comparison of mRNA levels for patients with detectable and undetectable cytokine levels. For most of the angioregulatory mediators we did not find any significant correlations between protein/mRNA levels or difference in mRNA levels between patients with detectable and undetectable mediator release. However, two exceptions were seen: (i) patients with undetectable HGF release had a significantly lower HGF-mRNA expression ( $\mathrm{p}=0.0079$, Mann-Whitney U-test, Fig. 3); and (ii) Ang-2 mRNA expression showed a significant correlation with supernatant protein levels $(\mathrm{p}=0.0245$, $\mathrm{r}=0.618$, Pearson's correlation, Fig. 3). Thus, only these two cytokines show evidence for a regulation of protein expression at the mRNA level.

\section{Pharmacological targeting of the PI3K/Akt/ mTOR pathway has antiproliferative effects on stromal cells}

Drug effects on stromal cell proliferation were examined using the ${ }^{3} \mathrm{H}$-thymidine incorporation assay. All stromal cells were treated with drugs over a wide concentration range and dose-dependent antiproliferative effects were observed (Fig. 4). However the effects varied between different cell types and between different drugs:

The mTOR inhibitors rapamycin and temsirolimus generally showed a weaker maximal inhibitory effect than the PI3K inhibitors. These two drugs showed very similar inhibitory effects on stromal cell proliferation with only minimal differences between drugs.

The PI3K inhibitors demonstrated a significant decrease in proliferation only for the highest concentration used in this study. The specific class I PI3K inhibitor GDC-0941 showed a $40 \%$ inhibition for all cell lines at the highest concentration, whereas the class III inhibitor 3-MA caused a similar inhibitory effect but only for certain cell lines.

The different cell lines also varied in their susceptibility to the pharmacological interventions. HUVECs showed less susceptibility to pharmacological 
interventions, whereas the osteoblastic Cal72 and the fibroblast HFL1 cell line also had a slightly more resistant profile.

Thus, all four drugs show inhibitory effects on stromal cell release of various cytokines at drug concentrations that also have similar inhibitory effects in primary human AML cells.

\section{Pharmacological interventions have diverse effect on cytokine release from bone marrow stromal cells}

We also investigated the effects of pharmacological intervention on the cell release of angioregulatory mediators after treatment with rapamycin $1 \mu \mathrm{M}$, temsirolimus $0.1 \mu \mathrm{M}$, GDC-0941 $1 \mu \mathrm{M}$ and 3-MA $10 \mathrm{mM}$. These concentrations were selected because the drugs then showed a clear antiproliferative effect for the majority of susceptible cell lines. For ten investigated stromal cell lines/primary cells, the pharmacological effects on the constitutive release of 13 angioregulatory mediators were examined including CXCL8-12, Ang-1/2, VEGF, HGF, bFGF MMP-2, MMP-9 and MMP-10 (Table 5) and the results were compared with the effects on AML cells (see Table 4):

Disruption of the PI3K/Akt/mTOR pathway generally increased the release of CXCL12 and CXCL8 by stromal cells, except for inhibitory effects observed for GDC-0941. CXCL8 was released at high levels by primary AML cells for most patients and only GDC-0941 inhibited the release.

The antiangiogenic CXCL9, CXCL10 and CXCL11 were not released at detectable levels by any stromal cell types. All three antiangiogenic mediators were released by AML cells and all PI3K/mTOR inhibitors generally inhibited their release.

The release of Ang-1 and to a lesser degree Ang2 was inhibited by the PI3K/mTOR inhibitors both for stromal and AML cells.

The inhibitors had divergent effects on VEGF release both for stromal and AML cells.

HGF was not released by stromal cells, but was commonly released by AML cells, and treatment with the four PI3K/mTOR inhibitors then reduced this release.

Stromal cells released detectable MMP-2 and MMP10 , but only undetectable or low levels of MMP-9. The $\mathrm{PI} 3 \mathrm{~K} / \mathrm{mTOR}$ inhibitors generally decreased MMP-2 levels, but increased MMP-10 release by stromal cells. In contrast, AML cells released MMP-2 and MMP-9 and levels were decreased by treatment with all PI3K/mTOR inhibitors.

Thus, PI3K/mTOR inhibitors affect stromal cell cytokine release at the same concentrations that affect the release by the primary AML cells, and the drugs seem to
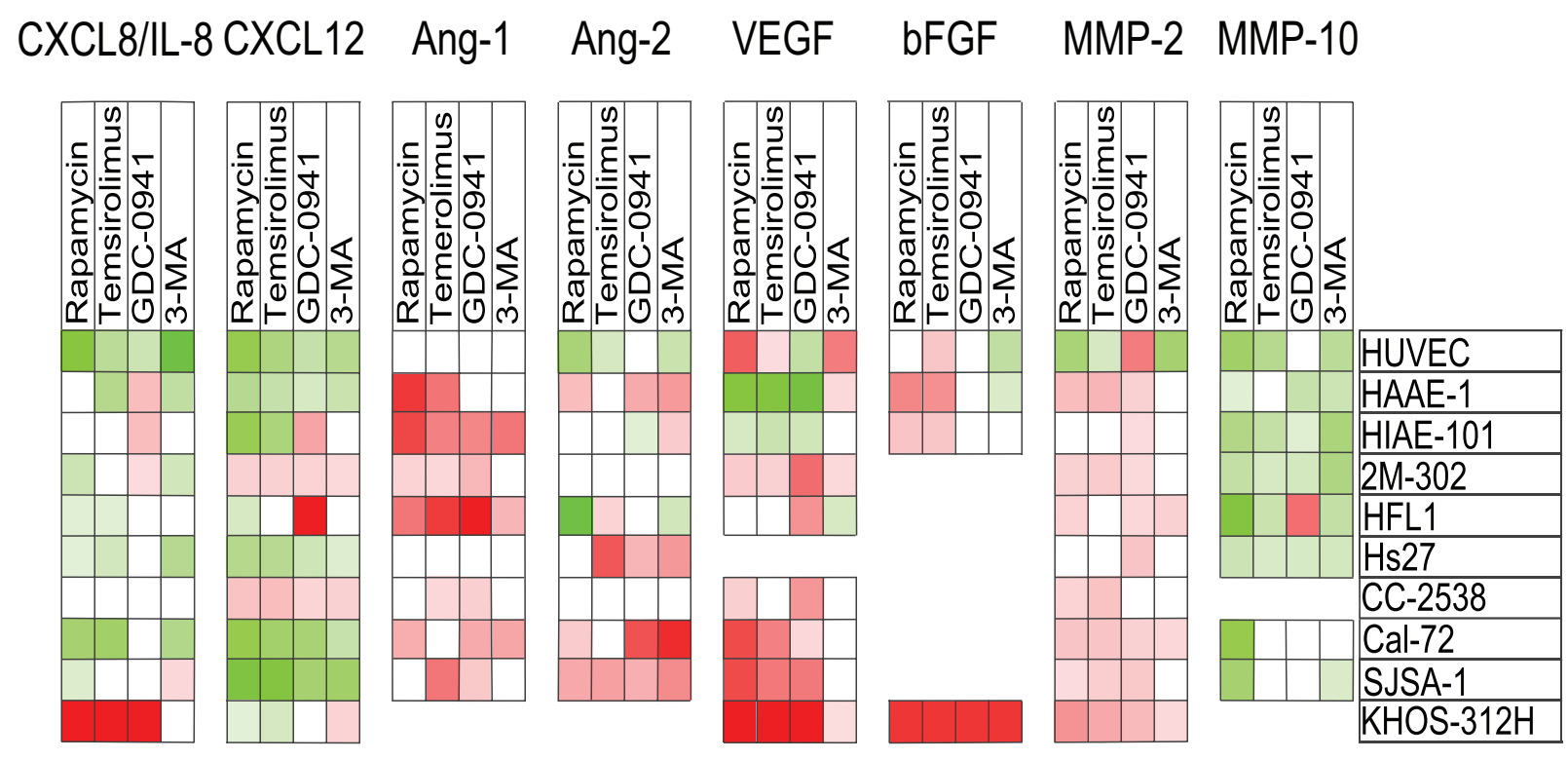

\section{Inhibitory Stimulatory}

Figure 4: Antiproliferative effects of $m$ TOR and PI3K inhibitors on stromal cells. The effects of mTOR (rapamycin, temsirolimus) and PI3K inhibition (GDC-0941, 3-MA) on in vitro proliferation of 11 different stromal cell populations was investigated using the ${ }^{3} \mathrm{H}$-thymidine incorporation assay. Detectable proliferation was defined as $>1000 \mathrm{cpm}$. Relative proliferation in drug-treated cultures versus the corresponding drug-free control cultures was converted to $\log (2)$ values. The different inhibitors and their concentration $(\mu \mathrm{M})$ are shown at the top and the cell type is shown in the far right column. The heatmap shows the effects of the different inhibitors on proliferation, i.e. red color indicates decreased growth and green color growth enhancement. 
have an overall proangiogenic effect on the chemokine release (maintained high CXCL8, decreased CXCL911 ); this effect is further supported by increased MMP10 release by stromal cells. The increased stromal cell release of CXCL12 may also stimulate leukemogenesis through effects on growth, survival and migration [26]. These AML-stimulating effects are counteracted by decreased HGF, Ang-1, VEGF and MMP-2 levels. The overall effects can only be explained by a specific effect of pharmacological PI3K-Akt-mTOR inhibition on the cytokine release; the effects cannot be explained by a nonspecific effect of decreased proliferation/viability because then a general decrease in the levels of all cytokines would be expected. It is thereby difficult to predict the final effect of PI3K/Akt/mTOR inhibition on bone marrow angioregulation as the effect will probably vary between patients.

\section{DISCUSSION}

The PI3K/Akt/mTOR pathway is implicated in leukemogenesis [27], and has emerged as a potential therapeutic target in AML $[6,7,14]$. Furthermore, several studies suggest a role of angiogenesis in human AML, and this process is regulated by various angioregulatory soluble mediators derived both from the leukemic cells and from the neighboring stromal cells in the bone marrow microenvironment $[15,18,28]$. In the present study we show that inhibitors of the PI3K and mTOR pathway may affect leukemogenesis through inhibition of the constitutive release of angioregulatory mediators both when investigating primary AML cells derived from a large group of unselected patients [29] as well as bone marrow stromal cells $[23,24]$. The effects on stromal cells were detected at the same drug concentrations as for the AML cells.

As explained in Material and methods the doses of the various drugs used in our present experiments were selected based on the observations in previous studies and pilot dose-response experiments with primary human AML cells. Our intention was to investigate whether these drugs have simultaneous effects both on leukemic and stromal cells and thus mediate their effects on AML cells both through direct and indirect effects (i.e. via neighboring stromal cells). For this reason we used the same concentrations both in AML and stromal cell experiments. The similarities between the various drugs with regard to their functional effects both in leukemic and stromal cells further support that the effects are mediated through common targets (i.e. the PI3K-Akt-mTOR pathway) and not through off-target effects, and this is also consistent with previous experiments [30-40].

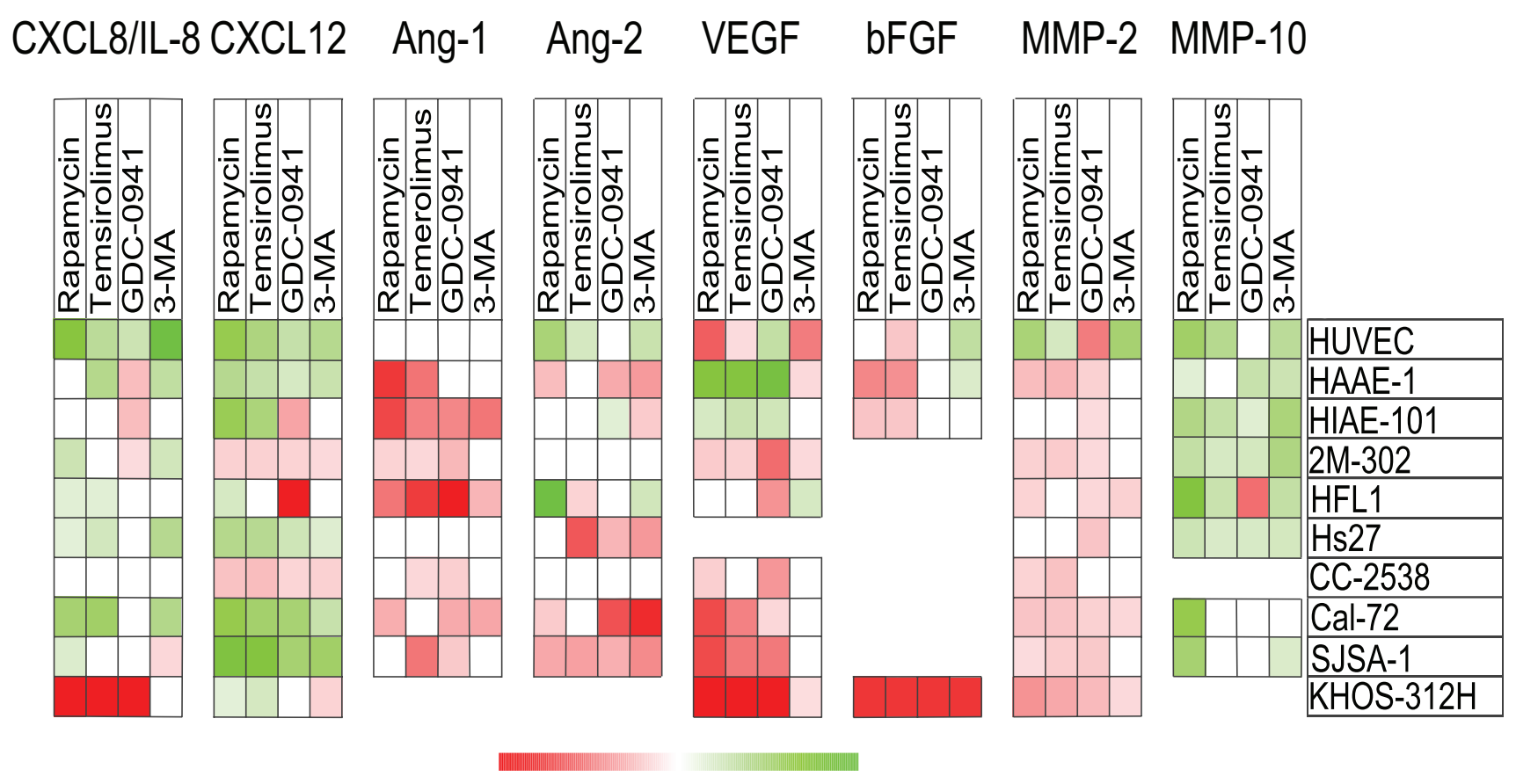

\section{Inhibitory Stimulatory}

Figure 5: Effects of $\mathrm{mTOR}$ and PI3K inhibitors on constitutive release of angiogenic mediators by stromal cells. The effects of mTOR (rapamycin, temsirolimus) and PI3K inhibition (GDC-0941, 3-MA) on in vitro constitutive mediator release was investigated for 10 different stromal cell populations. Cell supernatants were harvested from stromal cell cultures before confluence was reached. Levels of each mediator were determined using ELISA, and relative values (levels in drug-treated cultures divided by levels in corresponding control cultures) were $\log (2)$ converted. Squares are omitted where no detectable levels of mediators were measured in control/treated cultures. The various stromal cell populations examined are indicated in the right column. 
Angiogenesis is defined as the formation of new capillaries from pre-existing blood vessels, and the associations between levels of angiogenic mediators and survival after intensive chemotherapy suggest that angioregulation is also important for chemosensitivity in human AML [41-44]. Several mediators contribute to angioregulation in AML. Firstly, primary AML cells release several pro- (e.g. CXCL8) and antiangiogenic (e.g. CXCL9-11) chemokines, but the chemokine release profile differs between patients [45]. Secondly, AML cells release several MMPs, and MMP-9 seems to be associated with chemokine release, in contrast to MMP-2 which possibly is associated with prognosis after chemotherapy [41]. Finally, other important angioregulatory cytokines that seem to be associated with prognosis in human AML are the Ang-1/2 system, HGF and VEGF [15, 43, 44, 46].

In the present study, we analyzed the constitutive release profile for 10 angioregulatory mediators commonly released by primary human AML cells [47], and we compared the release for 60 unselected patients. Relatively high levels of proangiogenic CXCL8 were detected for almost all patients and this chemokine clustered separately, whereas the antiangiogenic CXCL9-11 clustered together and usually showed lower levels than CXCL8 and for most patients CXCL10 levels were higher than CXCL9/11 levels. These variations in constitutive chemokine release were the major contributors to the classification of patients into two major clusters in the hierarchical cluster analysis based on constitutive release of angioregulatory mediators (Fig. 1). Finally, we observed a wide variation in the pharmacological effects on constitutive mediator release between patients, but the inhibitory effects on chemokine release were most important for the classification/ clustering of patients into two major subsets based on effects of $\mathrm{PI} 3 \mathrm{~K} / \mathrm{Akt} / \mathrm{mTOR}$ inhibition on the constitutive release of angiogenic mediators (Fig. 2). Finally, clinical or biological characteristics of our patients showed no association with the clustering based on constitutive release of mediators alone or pharmacological effects on the constitutive release (Fig. 1 and Fig. 2).

Bone marrow stromal cells contribute to the local cytokine network and can thereby regulate leukemic hematopoiesis both through direct effects on the malignant cells and through indirect effects via other cells in the bone marrow microenvironment, e.g. the constitutive release of angioregulatory mediators by various stromal cells can affect leukemogenesis through effects on endothelial cells and thereby stimulate angiogenesis and disease development as suggested by previous experimental studies $[15,16,18,20,23,28]$. Potential new therapeutic agents should therefore be evaluated both for their direct effects on AML cells and also for their indirect antileukemic effects through nonleukemic stromal cells. Our present results suggest that such indirect pharmacological effects on stromal cells may contribute to the antileukemic effects of PI3K/Akt/mTOR inhibitors.
The PI3K and mTOR inhibitors evaluated in this study inhibited growth of bone marrow stromal cells, suggesting that they have indirect antileukemic effects mediated via the stromal cells. Previous studies have shown that these drugs have antiangiogenic and thereby anticancer effects in human malignancies [48, 49], including by decreased expression of both VEGF and its receptors $[48,50]$. However, our results show that disruption of the $\mathrm{PI} 3 \mathrm{~K} / \mathrm{Akt} / \mathrm{mTOR}$ pathway can affect angiogenesis not only via the VEGF system but also through altered release of several angioregulatory mediators released both by AML as well as various stromal cells. Such indirect effects may thus contribute to the antileukemic activity of these drugs [51]. Finally, another effect of these drugs seems to be altered leukemia cell migration [52] that may be caused by effects on stromal cells cytokine release and possibly affect localization of AML cells to the growth-enhancing stem cell niches.

The final effect of these drugs on angioregulation depends on their effects on the local balance between pro- and antiangiogenic mediators. Our overall results suggest that these drugs often have a relatively weak effect on proangiogenic CXCL8 that is released at high levels by AML cells for most patients; a strong inhibitory effect on this proangiogenic mediator was only seen for a subset of patients and an increased release was often seen for the stromal cells. The drugs had divergent effects on several other mediators (see Table 5 and Fig. 5) and it is possible that other growth factors/cytokines involved in AML-stroma interactions may be targeted by PI $3 \mathrm{~K} / \mathrm{mTOR}$ inhibitors. It is therefore difficult to predict the final overall effect of these drugs on bone marrow angioregulation, though in our opinion it seems most likely that the final effect will differ between individual patients, and for many patients antiangiogenic effects do not seem to be a major contributor to the antileukemic effects seen by the investigated PI3K/Akt/mTOR inhibitors and may also involve microenvironment-mediated drug-resistance [53, 54].

To conclude, our present results suggest that disrupting PI3K/Akt/mTOR signaling can alter the local bone marrow cytokine network both through effects on leukemia cells as well as various stromal cells, and these alterations may directly affect the leukemic cells or indirectly affect leukemogenesis through altered regulation of bone marrow angiogenesis.

\section{MATERIAL AND METHODS}

\section{AML patients and cell preparation}

The study was approved by the local Ethics Committee (Regional Ethics Committee III, University of Bergen, Norway) and samples collected after written 
informed consent. The study included a total of 60 consecutive adult AML patients with high peripheral blood blast counts $\left(>7 \times 10^{9} / \mathrm{L}\right)$. This selection of patients and the analysis of FLT3 and NPM1 mutations have been described previously $[29,46]$. The major characteristics of the 60 patients (median age 65.5 years, range $24-84$ years) are summarized in Table 1. AML cells were isolated from peripheral blood by density gradient separation (Lymphoprep, Axis-Shield, Oslo, Norway) and the final leukemic cell populations studied contained at least $95 \%$ leukemia blasts. The cells were stored in liquid nitrogen [29].

\section{Normal stromal cells and cell lines}

All human cell lines and primary cells were grown and expanded in their recommended media (distributor's information) and obtained from either Deutsche Sammlung von Zellkulturen und Mikroorganismen (DSZM, Braunschweig, Germany), American Type Culture Collection (ATCC Vanassas, MA) or Lonza (Cambrex BioScience, Walkersville, MD) as stated below. Primary cells were utilized at passages 2 to 4 . The following cell types were included in the study:

Human Umbilical Vein Endothelial Cells (HUVEC) (ATCC no C2517A) and the two arterial endothelial cell types; HAAE-1 (ATCC no CRL-2472) and HIAE-101 (ATCC no CRL-2478).

Normal bone marrow stromal cells (2M-302; Lonza) and the fibroblast cell lines HFL1 (ATCCs no CCL-153) and Hs27 (ATCC no CRL-1634).

Normal osteoblasts (Clonetics, Normal Human Osteoblast Cell System NHOst, CC-2538) and the two osteoblastic osteosarcoma cell lines Cal72 (DSZM) and SJSA-1 (ATCC no CRL-2098).

We also included SAOS (ATCC no HTB-85), SKES-1 (ATCC no HTB-86), U2OS (ATCC no HTB-96), which are osteoblastic sarcoma cell lines with an epithelial phenotype, and the adherent Ewing sarcoma cell line KHOS-312H (ATCC no CRL-1546).

\section{Pharmacological agents}

All the drugs were tested in initial dose-response experiments for primary human AML cells derived from 15 unselected patients; we then used a highly standardized ${ }^{3} \mathrm{H}$-thymidine incorporation assay for cytokine-dependent proliferation as published in previous methodological studies [45, 55-57]. All drugs inhibited AML cell proliferation at the concentrations used in the present experiments. Stock solutions of rapamycin and temsirolimus were prepared in dimethylsulphoxide (DMSO), and pilot experiments showed that DMSO at the concentrations reached in the experiments did not affect AML cell proliferation. Thus, all drugs were tested at concentrations showing biological effects on primary AML cells, and these effects were not caused by other constituents of the drug preparation. We wanted to investigate whether the drugs have combined direct and indirect (i.e. effects mediated via stromal cells) antileukemic effects, and for this reason we used the same drug concentrations in stromal cell experiments as in the AML cell studies.

\section{Rapamycin.}

Rapamycin (LC Laboratories, Woburn, MA) inhibits both mTORC1 and mTORC2 [30]. Initially we investigated the effect of rapamycin as a tenfold dilution between 0.01 and $10^{5} \mathrm{nM}$. All concentrations caused a similar and statistically significant inhibition of AML cell proliferation corresponding to $68 \%(0.01$ and $\left.10^{4} \mathrm{nM}\right)$ to $77 \%\left(10^{3} \mathrm{nM}\right)$ of the drug-free controls. Studies in myeloma cells have also shown a similar antiproliferative effect when rapamycin was tested over a similar concentration range [31], and previous in vitro studies of primary human AML cells suggest that some patients show no inhibition of mTOR activity when testing rapamycin at $\leq 20 \mathrm{nM}$ but with a maximal effect being reached at rapamycin $>50 \mathrm{nM}$ [32]. Based on these overall data we used rapamycin $100 \mathrm{nM}$ in our experiments.

\section{Temsirolimus.}

This rapamycin-derivative (LC Laboratories, Woburn, MA, US) causes an inhibition of both mTORC1 and mTORC2 when tested at high concentrations corresponding to $1250 \mathrm{nM}$ [33], whereas detailed studies in cancer cell lines have demonstrated that for concentrations up to $500 \mathrm{nM}$ temsirolimus is an mTORC1specific inhibitor [34]. We used temsirolimus at $100 \mathrm{nM}$; this concentration is within the range corresponding to selective mTORC1 inhibition, it has an antiproliferative effect in primary human AML cells and it has been used in previous experimental studies [4, 34].

\section{GDC-0941.}

This PI3K class I specific inhibitor (Axon Medchem $\mathrm{BV}$, Groningen, Netherlands) was tested at $100 \mathrm{nM}[35$, 36].

\section{3-methyladenine (3-MA)}

This is an inhibitor of both class I and class III PI3Ks and its biological effects are caused by effects on mTOR as well as other downstream targets of Akt [37-40] 3-MA (Sigma-Aldrich Corp. St. Louis, MO) was tested at $1 \mathrm{mM}[37-40]$ and $10 \mathrm{mM}$. 


\section{Analysis of constitutive release of soluble mediators by primary AML cells and stromal cells}

\section{Culture of AML cells}

The methodological approach for analysis of constitutive cytokine release has been characterized in detail in previous methodological studies [45, 55-57]. Briefly, AML blasts $\left(2 \times 10^{6}\right.$ cells in $\left.2 \mathrm{ml}\right)$ were cultured in 24-well culture plates (Costar 3524; Cambridge, MA) for 48 hours in StemSpan SFEM serum-free medium (referred to as StemSpan; Stem Cell Technologies; Vancouver, BC, Canada) supplemented with $100 \mu \mathrm{g} / \mathrm{ml}$ of gentamicin. Supernatants were collected after 48 hours of culture at $37^{\circ} \mathrm{C}$ in a humidified atmosphere of $5 \% \mathrm{CO}_{2}$.

\section{Stromal cell culture}

The culture conditions for the stromal cells have been characterized in detail previously [23]. Briefly, stromal cell populations were cultured in Stem Span supplemented with $10 \%$ heat-inactivated fetal calf serum (FCS) (BioWhittaker, Veviers, Belgium) and $100 \mu \mathrm{g} / \mathrm{ml}$ of gentamicin in 24-well culture plates (Costar 3524), 2 x $10^{4}$ cells were then seeded per well. Supernatants were harvested before the cells reached confluence.

\section{Analysis of soluble mediator concentrations in supernatants.}

Mediator levels were determined using Quantikine enzyme-linked immunosorbent assays (ELISA) (R\&D Systems, Minneapolis, MN). All assays were performed strictly according to the manufacturer's instructions. The minimal detectable levels were CXCL8 $3.5 \mathrm{pg} / \mathrm{mL}$, CXCL9 3.8 pg/mL, CXCL10 1.7 pg/mL, CXCL11 13.9 $\mathrm{pg} / \mathrm{mL}$, CXCL12 $18 \mathrm{pg} / \mathrm{mL}$, basic fibroblast growth factor (b-FGF) $3.0 \mathrm{pg} / \mathrm{mL}$, vascular endothelial growth factor (VEGF) $5.0 \mathrm{pg} / \mathrm{mL}$, hepatocyte growth factor (HGF) 40 $\mathrm{pg} / \mathrm{mL}$, angiopoietin (Ang)-1 $3.5 \mathrm{pg} / \mathrm{mL}$, Ang-2 $8.3 \mathrm{pg} / \mathrm{ml}$, matrix metalloprotease (MMP)-2 $0.16 \mathrm{ng} / \mathrm{mL}$ and MMP-9 $0.16 \mathrm{ng} / \mathrm{mL}$ and MMP-10 $4.1 \mathrm{pg} / \mathrm{mL}$.

\section{RNA preparation, labeling and microarray hybridization}

Primary human AML cells were investigated without any further ex vivo manipulation after isolation by gradient separation. All microarray experiments were performed using the Illumina iScan Reader, which is based upon fluorescence detection of biotin-labeled cRNA. Frozen primary AML cells were thawed and total RNA was prepared as described previously [58]. Total RNA 300 ng from each sample was reversely transcribed, amplified and biotin-16-UTP-labeled using the Illumina TotalPrep RNA Amplification Kit (Applied Biosystems/
Ambion, Foster City, CA). Amount and quality of the biotin-labeled cRNA was controlled both by NanoDrop spectrophotometer analysis and by using the Agilent 2100 Bioanalyzer before $750 \mathrm{ng}$ cRNA was hybridized to the HumanHT-12 v4 Expression BeadChip. The HumanHT-12 v4 BeadChip targets 47231 probes derived primarily from genes in the NCBI RefSeq database (Release 38).

\section{Analysis of stromal cell proliferation}

Stromal cells $\left(5 \times 10^{3}\right.$ cells/well $)$ were cultured in flat-bottomed microtitre 96-well plates (NucleonTM Surface, Nunc A/S, Roskilde, Denmark), with $150 \mu \mathrm{l}$ medium per well. All experiments were prepared in triplicates. Before cells reached confluency, ${ }^{3} \mathrm{H}$-thymidine $37 \mathrm{kBq}$ per well (TRA 310, Amersham, UK) was added in $20 \mu \mathrm{l}$ of $0.9 \% \mathrm{NaCl}$ solution and nuclear radioactivity was assayed 24 hours later. Cultures were then transferred to UniFilter-96 well GF/C plates (PerkinElmer Inc., Wellesley, MA), Microscint ${ }^{\mathrm{TM}}$ scintillation fluid was added (PerkinerElmer Inc.) to air dried plates and radioactivity was measured using a scintillation plate reader (TopCount $\mathrm{NXT}^{\mathrm{TM}}$, Packard Instruments, PerkinElmer Inc).

\section{Statistical and bioinformatical analyses}

All statistical analyses were performed using the Statistical Package for the Social Sciences (SPSS) v16.0 (SPSS Inc., Chicago, IL) and GraphPad Prism v5 (GraphPad Software, Inc., San Diego, CA), and p-values $<0.05$ were regarded as statistically significant. The data obtained from the scanning of arrays with the Illumina iScan Reader were analyzed using GenomeStudio and J-Express 2012 software for quality control measures [59]. All arrays within each experiment were quantile normalized to be comparable and then compiled into an expression profile data matrix,. Bioinformatical analyses were performed using the J-Express 2012 analysis suite (MolMine AS, Bergen, Norway) [59]. The normalized values were transformed to logarithmic values (base 2) before analyses, and unsupervised hierarchical clustering was performed with correlation and distance measure.

\section{ACKNOWLEDGMENTS}

The study received support from the Norwegian Cancer Society.

\section{DISCLOSURES}

None. 


\section{REFERENCES}

1 Estey EH: Acute myeloid leukemia: 2012 update on diagnosis, risk stratification, and management. Am J Hematol. 2012;87: 89-99.

2 Burnett A, Wetzler M, Lowenberg B: Therapeutic advances in acute myeloid leukemia. J Clin Oncol. 2011;29: 487-94.

3 Stapnes C, Gjertsen BT, Reikvam H, Bruserud O: Targeted therapy in acute myeloid leukaemia: current status and future directions. Expert Opin Investig Drugs. 2009;18: 433-55.

4 Chiarini F, Lonetti A, Teti G, Orsini E, Bressanin D, Cappellini A, Ricci F, Tazzari PL, Ognibene A, Falconi M, Pagliaro P, Iacobucci I, Martinelli G, Amadori S, McCubrey JA, Martelli AM: A combination of temsirolimus, an allosteric mTOR inhibitor, with clofarabine as a new therapeutic option for patients with acute myeloid leukemia. Oncotarget. 2012;3: 1615-28.

5 Altman JK, Sassano A, Platanias LC: Targeting mTOR for the treatment of AML. New agents and new directions. Oncotarget. 2011;2: 510-7.

6 Martelli AM, Evangelisti C, Chiarini F, McCubrey JA: The phosphatidylinositol 3-kinase/Akt/mTOR signaling network as a therapeutic target in acute myelogenous leukemia patients. Oncotarget. 2010;1: 89-103.

7 Park S, Chapuis N, Tamburini J, Bardet V, CornilletLefebvre P, Willems L, Green A, Mayeux P, Lacombe C, Bouscary D: Role of the PI3K/AKT and mTOR signaling pathways in acute myeloid leukemia. Haematologica. 2010;95: 819-28.

8 Martelli AM, Evangelisti C, Follo MY, Ramazzotti G, Fini M, Giardino R, Manzoli L, McCubrey JA, Cocco L: Targeting the phosphatidylinositol 3-kinase/Akt/ mammalian target of rapamycin signaling network in cancer stem cells. Curr Med Chem. 2011;18: 2715-26.

9 Willems L, Tamburini J, Chapuis N, Lacombe C, Mayeux $\mathrm{P}$, Bouscary D: PI3K and mTOR signaling pathways in cancer: new data on targeted therapies. Curr Oncol Rep. 2012;14: 129-38.

10 Venkannagari S, Fiskus W, Peth K, Atadja P, Hidalgo M, Maitra A, Bhalla KN: Superior efficacy of co-treatment with dual PI3K/mTOR inhibitor NVP-BEZ235 and panhistone deacetylase inhibitor against human pancreatic cancer. Oncotarget. 2012;3: 1416-27.

11 Amadori S, Stasi R, Martelli AM, Venditti A, Meloni G, Pane F, Martinelli G, Lunghi M, Pagano L, Cilloni D, Rossetti E, Di Raimondo F, Fozza C, Annino L, Chiarini F, Ricci F, Ammatuna E, La Sala E, Fazi P, Vignetti M: Temsirolimus, an mTOR inhibitor, in combination with lower-dose clofarabine as salvage therapy for older patients with acute myeloid leukaemia: results of a phase II GIMEMA study (AML-1107). Br J Haematol. 2012;156: 205-12.

12 Ghobrial IM, Weller E, Vij R, Munshi NC, Banwait R,
Bagshaw M, Schlossman R, Leduc R, Chuma S, Kunsman J, Laubach J, Jakubowiak AJ, Maiso P, Roccaro A, Armand P, Dollard A, Warren D, Harris B, Poon T, Sam A, Rodig $\mathrm{S}$, Anderson KC, Richardson PG: Weekly bortezomib in combination with temsirolimus in relapsed or relapsed and refractory multiple myeloma: a multicentre, phase $1 / 2$, open-label, dose-escalation study. Lancet Oncol. 2011;12: 263-72.

13 Perl AE, Kasner MT, Tsai DE, Vogl DT, Loren AW, Schuster SJ, Porter DL, Stadtmauer EA, Goldstein SC, Frey NV, Nasta SD, Hexner EO, Dierov JK, Swider CR, Bagg A, Gewirtz AM, Carroll M, Luger SM: A phase I study of the mammalian target of rapamycin inhibitor sirolimus and MEC chemotherapy in relapsed and refractory acute myelogenous leukemia. Clin Cancer Res. 2009;15: 6732-9.

14 Martelli AM, Chiarini F, Evangelisti C, Cappellini A, Buontempo F, Bressanin D, Fini M, McCubrey JA: Two hits are better than one: targeting both phosphatidylinositol 3-kinase and mammalian target of rapamycin as a therapeutic strategy for acute leukemia treatment. Oncotarget. 2012;3: 371-94.

15 Hatfield K, Oyan AM, Ersvaer E, Kalland KH, Lassalle P, Gjertsen BT, Bruserud O: Primary human acute myeloid leukaemia cells increase the proliferation of microvascular endothelial cells through the release of soluble mediators. Br J Haematol. 2009;144: 53-68.

16 Reikvam H, Hatfield KJ, Lassalle P, Kittang AO, Ersvaer E, Bruserud O: Targeting the angiopoietin (Ang)/Tie-2 pathway in the crosstalk between acute myeloid leukaemia and endothelial cells: studies of Tie-2 blocking antibodies, exogenous Ang-2 and inhibition of constitutive agonistic Ang-1 release. Expert Opin Investig Drugs. 2010;19: 16983.

17 Bruserud O, Ryningen A, Wergeland L, Glenjen NI, Gjertsen BT: Osteoblasts increase proliferation and release of pro-angiogenic interleukin 8 by native human acute myelogenous leukemia blasts. Haematologica. 2004;89: 391-402.

18 Hatfield K, Ryningen A, Corbascio M, Bruserud O: Microvascular endothelial cells increase proliferation and inhibit apoptosis of native human acute myelogenous leukemia blasts. Int J Cancer. 2006;119: 2313-21.

19 Schmidt T, Carmeliet P: Angiogenesis: a target in solid tumors, also in leukemia? Hematology Am Soc Hematol Educ Program. 2011;2011: 1-8.

20 Hatfield KJ, Evensen L, Reikvam H, Lorens JB, Bruserud O: Soluble mediators released by acute myeloid leukemia cells increase capillary-like networks. Eur J Haematol. 2012;89: 478-90.

21 Ribatti D, Nico B, Crivellato E, Roccaro AM, Vacca A: The history of the angiogenic switch concept. Leukemia. 2007;21: 44-52.

22 Rochet N, Leroy P, Far DF, Ollier L, Loubat A, Rossi B: CAL72: a human osteosarcoma cell line with unique effects on hematopoietic cells. Eur J Haematol. 2003;70: 43-52. 
23 Bruserud O, Tronstad KJ, Berge R: In vitro culture of human osteosarcoma cell lines: a comparison of functional characteristics for cell lines cultured in medium without and with fetal calf serum. J Cancer Res Clin Oncol. 2005;131: 377-84.

24 Glenjen NI, Hatfield K, Bruserud O: Coculture of native human acute myelogenous leukemia blasts with fibroblasts and osteoblasts results in an increase of vascular endothelial growth factor levels. Eur J Haematol. 2005;74: 24-34.

25 Hatfield KJ, Olsnes AM, Gjertsen BT, Bruserud O: Antiangiogenic therapy in acute myelogenous leukemia: targeting of vascular endothelial growth factor and interleukin 8 as possible antileukemic strategies. Curr Cancer Drug Targets. 2005;5: 229-48.

26 Kittang AO, Hatfield K, Sand K, Reikvam H, Bruserud O: The chemokine network in acute myelogenous leukemia: molecular mechanisms involved in leukemogenesis and therapeutic implications. Curr Top Microbiol Immunol. 2010;341: 149-72.

27 Peng C, Chen Y, Li D, Li S: Role of Pten in leukemia stem cells. Oncotarget. 2010;1: 156-60.

28 Hatfield KJ, Reikvam H, Bruserud O: The crosstalk between the matrix metalloprotease system and the chemokine network in acute myeloid leukemia. Curr Med Chem. 2010;17: 4448-61.

29 Bruserud O, Hovland R, Wergeland L, Huang TS, Gjertsen BT: Flt3-mediated signaling in human acute myelogenous leukemia (AML) blasts: a functional characterization of Flt3-ligand effects in AML cell populations with and without genetic Flt3 abnormalities. Haematologica. 2003;88: 416-28.

30 Sarbassov DD, Ali SM, Sengupta S, Sheen JH, Hsu PP, Bagley AF, Markhard AL, Sabatini DM: Prolonged rapamycin treatment inhibits mTORC2 assembly and Akt/ PKB. Mol Cell. 2006;22: 159-68.

31 Francis LK, Alsayed Y, Leleu X, Jia X, Singha UK, Anderson J, Timm M, Ngo H, Lu G, Huston A, Ehrlich LA, Dimmock E, Lentzsch S, Hideshima T, Roodman GD, Anderson KC, Ghobrial IM: Combination mammalian target of rapamycin inhibitor rapamycin and HSP90 inhibitor 17-allylamino-17-demethoxygeldanamycin has synergistic activity in multiple myeloma. Clin Cancer Res. 2006;12: 6826-35.

32 Perl AE, Kasner MT, Shank D, Luger SM, Carroll M: Single-cell pharmacodynamic monitoring of S6 ribosomal protein phosphorylation in AML blasts during a clinical trial combining the mTOR inhibitor sirolimus and intensive chemotherapy. Clin Cancer Res. 2012;18: 1716-25.

33 Zeng Z, Sarbassov dos D, Samudio IJ, Yee KW, Munsell MF, Ellen Jackson C, Giles FJ, Sabatini DM, Andreeff M, Konopleva M: Rapamycin derivatives reduce mTORC2 signaling and inhibit AKT activation in AML. Blood. 2007;109: 3509-12.

34 Zhang H, Berel D, Wang Y, Li P, Bhowmick NA, Figlin
RA, Kim HL: A comparison of Ku0063794, a dual mTORC1 and mTORC2 inhibitor, and temsirolimus in preclinical renal cell carcinoma models. PLoS One. 2013;8: e54918.

35 Bressanin D, Evangelisti C, Ricci F, Tabellini G, Chiarini F, Tazzari PL, Melchionda F, Buontempo F, Pagliaro P, Pession A, McCubrey JA, Martelli AM: Harnessing the $\mathrm{PI} 3 \mathrm{~K} / \mathrm{Akt} / \mathrm{mTOR}$ pathway in T-cell acute lymphoblastic leukemia: eliminating activity by targeting at different levels. Oncotarget. 2012;3: 811-23.

36 Martin-Sanchez E, Rodriguez-Pinilla SM, Sanchez-Beato M, Lombardia L, Dominguez-Gonzalez B, Romero D, Odqvist L, Garcia-Sanz P, Wozniak MB, Kurz G, BlancoAparicio C, Mollejo M, Alves FJ, Menarguez J, GonzalezPalacios F, Rodriguez-Peralto JL, Ortiz-Romero PL, Garcia JF, Bischoff JR, Piris MA: Simultaneous inhibition of panphosphatidylinositol-3-kinases and MEK as a potential therapeutic strategy in peripheral T-cell lymphomas. Haematologica. 2013;98: 57-64.

37 Lin YC, Kuo HC, Wang JS, Lin WW: Regulation of inflammatory response by 3-methyladenine involves the coordinative actions on Akt and glycogen synthase kinase 3 beta rather than autophagy. J Immunol. 2012;189: 415464.

38 Heckmann BL, Yang X, Zhang X, Liu J: The autophagic inhibitor 3-methyladenine potently stimulates PKAdependent lipolysis in adipocytes. $\mathrm{Br} \mathrm{J}$ Pharmacol. 2013;168: 163-71.

39 Wu YT, Tan HL, Shui G, Bauvy C, Huang Q, Wenk MR, Ong CN, Codogno P, Shen HM: Dual role of 3-methyladenine in modulation of autophagy via different temporal patterns of inhibition on class I and III phosphoinositide 3-kinase. J Biol Chem. 2010;285: 1085061.

40 Ryningen A, Reikvam H, Nepstad I, Paulsen Rye K, Bruserud O: Inhibition of Mammalian target of rapamycin in human acute myeloid leukemia cells has diverse effects that depend on the environmental in vitro stress. Bone Marrow Res. 2012;2012: 329061.

41 Reikvam H, Hatfield KJ, Oyan AM, Kalland KH, Kittang AO, Bruserud O: Primary human acute myelogenous leukemia cells release matrix metalloproteases and their inhibitors: release profile and pharmacological modulation. Eur J Haematol. 2010;84: 239-51.

42 Loges S, Heil G, Bruweleit M, Schoder V, Butzal M, Fischer U, Gehling UM, Schuch G, Hossfeld DK, Fiedler $\mathrm{W}$ : Analysis of concerted expression of angiogenic growth factors in acute myeloid leukemia: expression of angiopoietin-2 represents an independent prognostic factor for overall survival. J Clin Oncol. 2005;23: 1109-17.

43 de Jonge HJ, Valk PJ, Veeger NJ, ter Elst A, den Boer ML, Cloos J, de Haas V, van den Heuvel-Eibrink MM, Kaspers GJ, Zwaan CM, Kamps WA, Lowenberg B, de Bont ES: High VEGFC expression is associated with unique gene expression profiles and predicts adverse prognosis 
in pediatric and adult acute myeloid leukemia. Blood. 2010;116: 1747-54.

44 Kim JG, Sohn SK, Kim DH, Baek JH, Lee NY, Suh JS, Chae SC, Lee KS, Lee KB: Clinical implications of angiogenic factors in patients with acute or chronic leukemia: hepatocyte growth factor levels have prognostic impact, especially in patients with acute myeloid leukemia. Leuk Lymphoma. 2005;46: 885-91.

45 Bruserud O, Ryningen A, Olsnes AM, Stordrange L, Oyan AM, Kalland KH, Gjertsen BT: Subclassification of patients with acute myelogenous leukemia based on chemokine responsiveness and constitutive chemokine release by their leukemic cells. Haematologica. 2007;92: 332-41.

46 Hatfield KJ, Hovland R, Oyan AM, Kalland KH, Ryningen A, Gjertsen BT, Bruserud O: Release of angiopoietin-1 by primary human acute myelogenous leukemia cells is associated with mutations of nucleophosmin, increased by bone marrow stromal cells and possibly antagonized by high systemic angiopoietin-2 levels. Leukemia. 2008;22: 287-93.

47 Dimberg A: Chemokines in angiogenesis. Curr Top Microbiol Immunol. 2010;341: 59-80.

48 Mirshahi P, Toprak SK, Faussat AM, Dubrulle S, Marie JP, Soria C, Soria J, Mirshahi M: Malignant hematopoietic cells induce an increased expression of VEGFR-1 and VEGFR-3 on bone marrow endothelial cells via AKT and mTOR signalling pathways. Biochem Biophys Res Commun. 2006;349: 1003-10.

49 Frost P, Moatamed F, Hoang B, Shi Y, Gera J, Yan H, Gibbons J, Lichtenstein A: In vivo antitumor effects of the mTOR inhibitor CCI-779 against human multiple myeloma cells in a xenograft model. Blood. 2004;104: 4181-7.

50 Bohm A, Aichberger KJ, Mayerhofer M, Herrmann H, Florian S, Krauth MT, Derdak S, Samorapoompichit P, Sonneck K, Vales A, Gleixner KV, Pickl WF, Sperr WR, Valent P: Targeting of mTOR is associated with decreased growth and decreased VEGF expression in acute myeloid leukaemia cells. Eur J Clin Invest. 2009;39: 395-405.

51 Qayum N, Im J, Stratford MR, Bernhard EJ, McKenna WG, Muschel RJ: Modulation of the Tumor Microvasculature by Phosphoinositide-3 Kinase Inhibition Increases Doxorubicin Delivery In Vivo. Clin Cancer Res. 2012;18: 161-9.

52 Liu P, Xu B, Li J, Lu H: LY294002 inhibits leukemia cell invasion and migration through early growth response gene 1 induction independent of phosphatidylinositol 3-kinaseAkt pathway. Biochem Biophys Res Commun. 2008;377: 187-90.

53 Zeng Z, Shi YX, Tsao T, Qiu Y, Kornblau SM, Baggerly KA, Liu W, Jessen K, Liu Y, Kantarjian H, Rommel C, Fruman DA, Andreeff M, Konopleva M: Targeting of mTORC1/2 by the mTOR kinase inhibitor PP242 induces apoptosis in AML cells under conditions mimicking the bone marrow microenvironment. Blood. 2012;120: 267989.
54 Willems L, Chapuis N, Puissant A, Maciel TT, Green AS, Jacque N, Vignon C, Park S, Guichard S, Herault O, Fricot A, Hermine O, Moura IC, Auberger P, Ifrah N, Dreyfus F, Bonnet D, Lacombe C, Mayeux P, Bouscary D, Tamburini $\mathrm{J}$ : The dual mTORC1 and mTORC2 inhibitor AZD8055 has anti-tumor activity in acute myeloid leukemia. Leukemia. 2012;26: 1195-202.

55 Bruserud O, Ulvestad E: Effects of gamma-irradiation on acute myelogenous leukemia blasts: in vitro studies of proliferation, constitutive cytokine secretion, and accessory cell function during T cell activation. J Hematother Stem Cell Res. 1999;8: 431-41.

56 Bruserud O, Gjertsen BT, von Volkman HL: In vitro culture of human acute myelogenous leukemia (AML) cells in serum-free media: studies of native AML blasts and AML cell lines. J Hematother Stem Cell Res. 2000;9: 923-32.

57 Reikvam H, Hatfield KJ,Ersvaer E, Hovland R, Skavland J, Gjertsen BT, Petersen K, Bruserud O. Expression profile of heat shock proteins in acute myeloid leukaemia patients reveals a distinct signature strongly associated with FLT3 mutation status - consequences and potentials for pharmacological intervention. Br J Haemtol. 2012;156: 468-80.

58 Gjertsen BT, Oyan AM, Marzolf B, Hovland R, Gausdal G, Doskeland SO, Dimitrov K, Golden A, Kalland KH, Hood L, Bruserud O: Analysis of acute myelogenous leukemia: preparation of samples for genomic and proteomic analyses. J Hematother Stem Cell Res. 2002;11: 469-81.

59 Stavrum AK, Petersen K, Jonassen I, Dysvik B: Analysis of gene-expression data using J-Express. Curr Protoc Bioinformatics. 2008; Chapter 7: Unit 73. 